\title{
MOLECULAR ANALYSIS OF FRIEDREICH'S ATAXIA IN MACEDONIAN PATIENTS
}

\author{
Kocheva $\mathrm{S}^{1,2}$, Trivodalieva $\mathrm{S}^{1}$, Vlaski-Jekic $\mathrm{S}^{3}$, Kuturec $\mathrm{M}^{2}$, Efremov GD ${ }^{1, *}$
}

\begin{abstract}
*Corresponding Author: Professor Dr. Georgi D. Efremov, Macedonian Academy of Sciences and Arts, Research Center for Genetic Engineering and Biotechnology, Aven Krste Misirkov 2, POB 428, 1000 Skopje, Republic of Macedonia; Tel: +3892-120253; Fax: +3892-115434; E-mail: gde@manu.edu
\end{abstract}

\begin{abstract}
Friedreich's ataxia (FRDA) is rare a progressive neurodegenerative disorder of autosomal recessive inheritance, which is associated with an unstable expansion of a GAA trinucleotide repeat in the first intron of the frataxin gene on chromosome $9 \mathrm{q} 13$. We have performed molecular analyses of the frataxin gene of 40 patients with spinocerebellar ataxia from the Republic of Macedonia. Fifteen had early onset of progressive ataxia (before the age of 25), while the remainder were over 25 years old at the time of diagnosis. Only 14 patients had a mutation in the frataxin gene and all of these had early onset ataxia. The number of GAA repeats was in the normal range in 50 healthy individuals.
\end{abstract}

\section{INTRODUCTION}

Friedreich ataxia (FRDA), is a progressive neurodegenerative disorder of autosomal recessive inheritance [1]. It is the most common hereditary ataxia, with an estimated prevalence of 1 in 50,000 [2-4], and a carrier frequency of about 1 in 120 in

Macedonian Academy of Sciences and Arts, Research Center for Genetic Engineering and Biotechnology, 1000 Skopje, Republic of Macedonia

2 Pediatric Clinic, Faculty of Medicine, 1000 Skopje, Republic of Macedonia

3 Neurology Clinic, Faculty of Medicine, 1000 Skopje, Republic of Macedonia the Caucasian population [5]. The cardinal feature is gait ataxia followed by upper limb ataxia, cerebellar dysarthria, nystagmus, areflexia, loss of joint position sense and spastic paraparesis [6], developing from the second decade of life. Hypertrophic cardiomyopathy occurs in almost all patients [7], diabetes mellitus in about $10 \%$ of patients, carbohydrate intolerance in an additional $20 \%$, and a reduced insulin response to arginine stimulation in all patients [8].

Friedreich's ataxia is associated with an unstable expansion of a GAA trinucleotide repeat in the first intron of the frataxin gene on chromosome 9 q13 [9]. Normal alleles contain five to 60 GAA repeats. The number of repeats in FRDA patients varies from 66 to 1,700, and results in a decreased expression of this gene [9-12], which probably leads to mitochondrial iron accumulation and free radical damage of oxidative phosphorylation processes $[13,14]$. In about $96 \%$ of the patients, both alleles are expanded, while $4 \%$ of patients are compound heterozygotes for GAA expansion in the diseasecausing range and an inactivating mutation [9].

Friedreich's ataxia shows broad clinical variability $[15,16]$. The Harding diagnostic criteria can be used to differentiate between typical and non typical FRDA cases, but the differential diagnosis from some of the juvenile spinocerebellar ataxias remains a clinical problem. Molecular analysis can be useful to confirm clinical diagnosis and to detect carriers. 


\section{MATERIALS AND METHOD}

Patients and Controls. Forty patients from the Republic of Macedonia with spinocerebellar ataxia referred to our institution for molecular diagnosis of FRDA, were studied. Fifteen had an early onset of progressive ataxia (before 25 years), while 25 were older than 25 years at the time of diagnosis. Fifty healthy individuals were also studied.

GAA Repeat Analysis. Genomic DNA was extracted from venous blood leukocytes using a standard phenol/ chloroform extraction procedure [17]. Amplification of normal and expanded alleles was obtained by long range polymerase chain reaction (PCR) procedures using primers that flank the GAA repeat in intron 1 of the frataxin gene (GAAF: 5'GGG ATT GGT TGC CAG TGC TTA AAA GTT AG-3' and GAAR: 5'-GAT CTA AGG ACC ATC ATG GCC ACA CTT GCC-3') and generate a PCR product of $457+3 n$ bp $(n=$ number of GAA repeats). Long-range PCR conditions, which gave efficient amplification, consisted of: 20 cycles at $94^{\circ} \mathrm{C}$ 's for 20 seconds, $68^{\circ} \mathrm{C}$ for $2 \mathrm{~min}$. and $72^{\circ} \mathrm{C}$ for $2 \mathrm{~min}$., followed by 17 cycles in which the length of the $68^{\circ} \mathrm{C}$ steps was increased by 15 seconds per cycle. The PCR products were analyzed by $1 \%$ agarose gel electrophoresis, visualized by ethidium bromide

A.

PCR in normal range $(457+$ GAA $)$

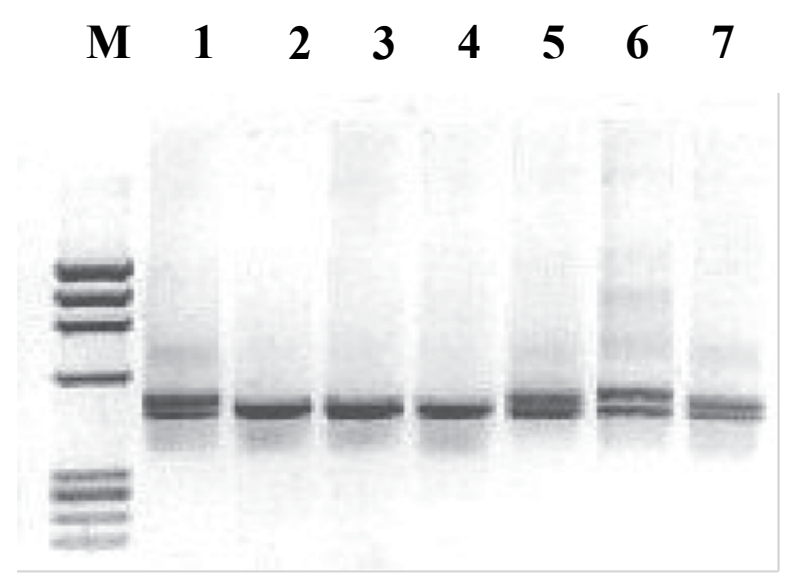

staining and recorded on a digital camera. The size of the PCR products was determined by comparing their migration rate with a molecular weight size standard [DNA molecular weight marker IX, 721353 bp (GE Healthcare Bio-Sciences AB, Uppsala, Sweden)].

\section{RESULTS AND DISCUSSION}

Representative electrophoregrams of PCR fragments from the amplification of GAA repeats in intron 1 of the frataxin gene in patients with FRDA and in healthy individuals are shown in Figure 1A and $1 \mathrm{~B}$, respectively. Polymerase chain reaction analyses of heterozygotes for expanded GAA alleles are shown in Figure 2.

Of the 15 patients diagnosed with spinal cerebellar ataxia before 25 years of age, 14 (93.3\%) were homozygous for the GAA expansion and all had two expanded alleles of same size and no detectable somatic instability. Only one patient with early onset of spinal cerebellar ataxia had two normal alleles, and this result excluded the diagnosis of FRDA. The 25 patients with late onset spinal cerebellar ataxia had two alleles in the normal size range (5-50 GAA repeats). Ten of these were heterozygotes and 15 were homozygous for normal alleles

B. Expanded fragment (app 1300bp)

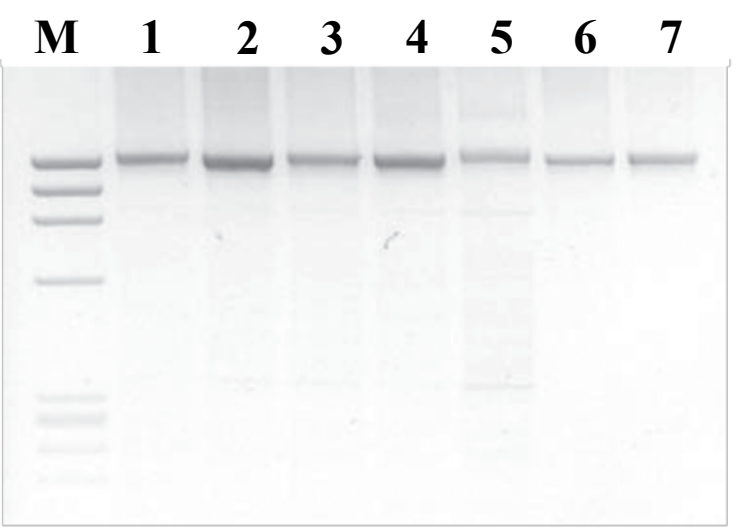

Figure 1. Agarose gel electrophoresis of PCR products of intron 1 of the frataxin gene in healthy individuals (lanes 1-7) with different numbers of GAA repeats (A), and of seven patients with FRDA (lanes 1-7) (B); M: molecular weight marker. 


\section{$\begin{array}{lllllll}M & 1 & 2 & 3 & 4 & 5 & 6\end{array}$}

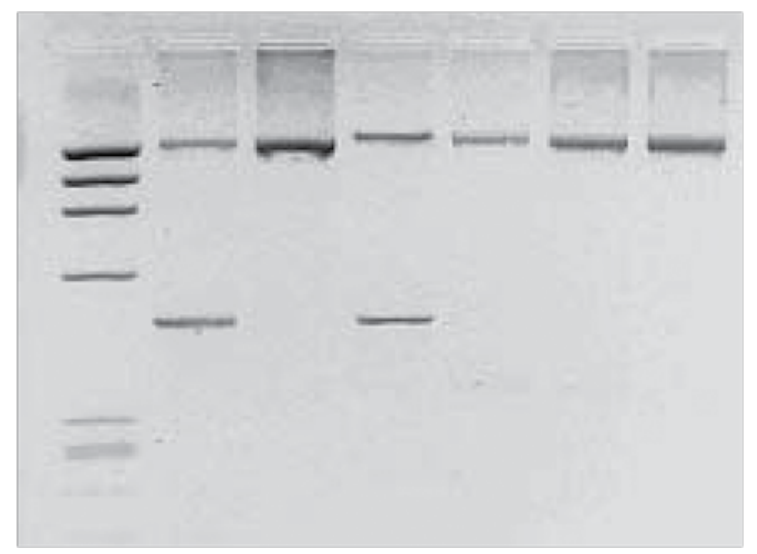

Expanded fragment (app 1300bp)

Normal range (app (457bp))

Figure 2. Agarose gel electrophoresis of PCR products of patients (lanes 2, 5 and 6) and members of families with FRDA (lanes 1 and 3), showing the normal and expanded fragment (lanes 1 and 3); M: molecular weight marker.

which excluded the diagnosis of FRDA. Molecular analysis of intron 1 of the frataxin gene in healthy individuals showed a range of GAA repeats from 5 to 50. Our results are concordant with already published data [1-4]. This long-range PCR protocol can be used as a diagnostic tool for FRDA and carrier detection.

\section{ACKNOWLEDGMENTS}

This study was supported by grants No. 4008662/98 from the Ministry of Science of the Republic of Macedonia and No. 11-513/1 from the science funds of the Macedonian Academy of Sciences and Arts, Skopje, Republic of Macedonia (both to GDE).

\section{REFERENCES}

1. Pandolfo M. Molecular genetics and pathogenesis of Friedreich ataxia. Neuromuscul Disord 1998; 8(6): 409-415.

2. Skre H. Friedreich's ataxia in Western Norway. Clin Genet 1975; 7(4): 287-298.

3. Winter RM, Harding AE, Baraitser M, Bravery MB. Intrafamilial correlation in Friedreich's ataxia. Clin Genet 1981; 20(6): 419-427.

4. Filla A, De Michele G, Marconi R, Bucci L, Carillo C, Castellano AE, Iorio L, Kniahynicki C,
Rossi F, Campanella G. Prevalence of hereditary ataxias and spastic paraplegias in Molise, a region of Italy. J Neurol 1992; 239(6): 351-353.

5. Epplen C, Epplen JT, Frank G, Miterski B, Santos EJM, Schols L. Differential stability of the (GAA)n tract in the Friedreich ataxia (STM7) gene. Hum Genet 1997; 99(6): 834-836.

6. Harding AE. Friedreich's ataxia: a clinical and genetic study of 90 families with an analysis of early diagnostic criteria and intrafamilial clustering of clinical features. Brain 1981; 104(3): 589-620.

7. Harding AE, Hewer RL. The heart disease of Friedreich's ataxia: a clinical and electrocardiographic study of 115 patients, with an analysis of serial electrocardiographic changes in 30 cases. Q J Med 1983; 52(208): 489-502.

8. Finocchiaro G, Baio G, Micossi P, Pozza G, Di Donato S. Glucose metabolism alterations in Friedreich's ataxia. Neurology 1988; 38(8), 1292-1296.

9. Campuzano V, Montermini L, Moltò MD, Pianese L, Cossée M, Cavalcanti F, Monros E, Rodius F, Duclos F, Monticelli A, Zara F, Canizares J, Koutnikova H, Bidichandani SI, Gellera C, Brice A, Trouillas, De Michele G, Filla A, De Frutos R, Palau F, Patel PI, Di Donato S, Mandel J-L, Cocozza S, Koenig M, Pandolfo M. Friedreich's ataxia: autosomal recessive disease caused by an intronic GAA triplet repeat expansion. Science 1996; 271(5254): 1423-1427. 
10. Filla A, De Michele G, Cavalcanti F, Pianese L, Monticelli A, Campanella G, Cocozza S. The relationship between trinucleotide (GAA) repeat length and clinical features in Friedreich ataxia. Am J Hum Genet 1996; 59(3): 554-560.

11. Cossée M, Schmitt M, Campuzano V, Reutenauer L, Moutou C, Mandel JL, Koenig M. Evolution of the Friedreich's ataxia trinucleotide repeat expansion: founder effect and premutations. Proc Natl Acad Sci USA 1997; 94(14): 7452-7457.

12. Campuzano V, Montermini L, Lutz Y, Cova L, Hindelang C, Jiralerspong S, Trottier Y, Kish SJ, Faucheux B, Trouillas P, Authier FJ, Durr A, Mandel JL, Vescovi A, Pandolfo M, Koenig M. Frataxin is reduced in Friedreich ataxia patients and is associated with mitochondrial membranes. Hum Mol Genet 1997; 6(11): 1771-1780.

13. Montermini L, Andermann E, Labuda M, Richter A, Pandolfo M, Cavalcanti F, Pianese L, Iodice L, Farina G, Monticelli A, Turano M, Filla A, De Michele G, Cocozza S. The Friedreich ataxia GAA triplet repeat: premutation and normal alleles. Hum Mol Genet 1997; 6(8): 1261-1266.
14. Rotig A, de Lonlay P, Chretien D, Foury F, Koenig M, Sidi D, Munnich A, Rustin P. Aconitase and mitochondrial iron-sulphur protein deficiency in Friedreich ataxia. Nat Genet 1997; 17(2): 215217.

15. De Michele G, Filla A, Cavalcanti F, Di Maio L, Pianese L, Castaldo I, Calabrese O. Late onset Friedreich's disease: clinical features and mapping of mutation to the FRDA locus. J Neurol Neurosurg Psychiatry 1994; 57(8): 977-979.

16. Palau F, De Michele G, Vilchez JJ, Pandolfo M, Monros E, Cocozza S, Smeyers P, Lopez-Arlandis J, Campanella G, Di Donato S, Filla A. Earlyonset ataxia with cardiomyopathy and retained tendon reflexes maps to the Friedreich's ataxia locus on chromosome 9q. Ann Neurol 1995; 37(3): 359362 .

17. Efremov G.D, Dimovski A.J, PlaseskaKaranfilska D, Simjanovsa L, Sukarova E, Koceva S, Popovski Z. Laboratory Manual, 2nd ed. 1998. ICGEB Affilated Center "Nucleic acid based methods in human and veterinary medicine." Skopje: Macedonian Academy of Sciences and Arts, 1998. 